ISSN 2083-3725
Authors' contribution/

Wkład autorów:

A. Zaplanowanie badań/

Study design

B. Zebranie danych/

Data collection

C. Analiza statystyczna/

Statistical analysis

D. Interpretacja danych/

Data interpretation

E. Przygotowanie tekstu/

Manuscript preparation

F. Opracowanie

piśmiennictwa/

Literature search

G. Pozyskanie funduszy/

Funds collection

\section{THE APPLICATION OF RAW MATERIALS OBTAINED FROM THE CULTIVATION OF INDUSTRIAL HEMP IN VARIOUS INDUSTRIES}

\section{WYKORZYSTANIE SUROWCÓW OTRZYMANYCH Z UPRAW KONOPI WŁÓKNISTYCH W RÓŻNYCH GAŁĘZIACH PRZEMYSŁU}

\author{
Przemysław Brzyski ${ }^{(B, D, E, F)}$, Stanisław Fic $\left.{ }^{(B, D, E,}\right)$ \\ Lublin University of Technology \\ Politechnika Lubelska
}

Brzyski P., Fic S. (2017), The application of raw materials obtained from the cultivation of industrial hemp in various industries/ Wykorzystanie surowców otrzymanych z upraw konopi włóknistych w różnych gałęziach przemysłu. Economic and Regional Studies. Vol. 10, No. 1, pp. 100-113. https://doi.org/10.2478/ers-2017-0008

\section{Summary}

\section{REVIEW ARTICLE}

JEL code: Q10

Submitted:

January 2016

Accepted:

December 2016

Tables: 1

Figures: 15

References: 26

ARTYKUŁ PRZEGLĄDOWY

Klasyfikacja JEL: Q10

Zgłoszony:

styczeń 2016

Zaakceptowany:

grudzień 2016

Tabele: 1

Rysunki: 15

Literatura: 26
Subject and purpose of work: The raw materials which are the purpose of the current hemp cultivation $(<0.2 \%$ THC $)$ are fibre, seeds and shives. This study describes the characteristics the raw materials obtained from the industrial hemp and described in detail the possibilities of their applications in pulp and paper, textile, pharmaceutical, construction and food industries.

Analysis of the issues: Hemp straw consists of a porous ligneous core, which may be cut into smaller pieces, called hemp shives and of the fibre around the core. Hemp cellulose is used to produce paper pulp or plastics. In the construction sector, hemp fibre is used to produce, among other things, thermal insulation materials. Hemp shives is used as a filler for a composite based on lime binder, which is used as a wall material with good hygrothermal conditions confirmed by proprietary research. Hemp seeds are used for the production of cooking oil. Hempseed oil is also used in the pharmaceutical industry, e.g. to produce skin creams.

Conclusions: Raw materials obtained from industrial hemp have a variety of applications. Currently, new directions in hemp application are being sought and tested, like for example hemp lime composite and bio-composites. The positive environmental impact resulting from the cultivation of hemp should be the main reason for simplifying the procedures for the commencement of its cultivation in many countries, e.g. in Poland.

Keywords: industrial hemp, fibre, seed, shives

\section{Streszczenie}

Przedmiot i cel pracy: Surowcami, dla których obecnie uprawia się konopie włókniste $(<0,2 \%$ THC są włókna, nasiona oraz paździerze. W pracy scharakteryzowano surowce pozyskane z konopi włóknistych oraz szczegółowo opisano możliwości ich zastosowania w przemyśle: celulozowo- papierniczym, włókienniczym, farmaceutycznym, budowlanym, spożywczym.

Analiza problematyki: Słoma konopna składa się z porowatego, drewnianego rdzenia, który może być pocięty na mniejsze części, zwane paździerzami oraz z włókna otaczającego dookoła rdzeń. Celuloza konopna wykorzystywana jest do produkcji masy papierowej oraz w produkcji tworzyw sztucznych. W sektorze budownictwa, włókna konopne stosowane są do produkcji m.in. materiałów termoizolacyjnych. Paździerze konopne wykorzystywane są jako wypełniacz kompozytu na bazie spoiwa wapiennego, stosowanego jako materiał ścienny o dobrych właściwościach cieplno-wilgotnościowych, co potwierdzają badania własne. Nasiona konopne stosowane są do produkcji oleju spożywczego. Olej znajduje również zastosowanie w przemyśle farmaceutycznym, np. w produkcji kremów do skóry.

Wnioski: Surowce pozyskane z konopi włóknistych znajdują wiele zastosowań. Obecnie poszukiwane i badane są nowe kierunki zastosowań konopi, jak np. kompozyty wapienno konopne oraz bio-kompozyty. Pozytywny wpływ środowiskowy wynikający z upraw konopi powinien być głównym powodem uproszczenia procedury rozpoczęcia upraw w wielu krajach, np. w Polsce.

Słowa kluczowe: konopie włókniste, włókna, nasiona, paździerze

Address for correspondence/ Adres korespondencyjny: mgr inż. Przemysław Brzyski, Politechnika Lubelska, Wydział Budownictwa i Architektury, ul. Nadbystrzycka 40, 20-618 Lublin, Polska; tel. +48609629 605; e-mail: p.brzyski@pollub.pl; prof. nadzw. dr hab. inż. Stanisław Fic, Politechnika Lubelska, Wydział Budownictwa i Architektury, ul. Nadbystrzycka 40, 20-618 Lublin, Polska; tel. +48 81538 44 43; e-mail: s.fic@pollub.pl

Journal indexed in/ Czasopismo indeksowane w: AgEcon Search, AGRO, BazEkon, Index Copernicus Journal Master List, ICV 2015: 81,26; Polish Ministry of Science and Higher Education 2016: 9 points / AgEcon Search, AGRO, BazEkon, Index Copernicus Journal Master List ICV 2015: 81,26; Ministerstwie Nauki i Szkolnictwa Wyższego 2016: 9 punktów. Copyright: (C) 2016 Pope John Paul II State School of Higher Education in Biała Podlaska, Przemysław Brzyski, Stanisław Fic. All articles are distributed under the terms of the Creative Commons Attribution-NonCommercial-ShareAlike 4.0 International (CC BY-NC-SA 4.0) License (http://creativecommons.org/licenses/by-nc-sa/4.0/), allowing third parties to copy and redistribute the material in any medium or format and to remix, transform, and build upon the material, provided the original work is properly cited and states its license. 


\section{Introduction}

Once known and widely used materials made of hemp have been replaced by popular, usually imported substitutes, which has led to almost complete disappearance of hemp cultivation from Polish agriculture. In recent years, increased public interest may be noted in Poland with regard to hemp (also known as industrial hemp) potential as a crop, whose intermediate products find many useful applications. The crop growing area has been increasing year over year and reached approximately 1.500 hectares in 2016. Increasingly farmers are selling their crops, mainly seeds, to Polish food producers who produce high-quality, healthy food from them. We can see the growth of the Polish market for the material, which so far has only been used as a bedding for animals or treated as waste -shives, which is becoming increasingly popular as a building material.

In Poland, the cultivation of hemp is regulated by the Act on Drug Abuse Prevention, which came into force on 24 April 1997 (Journal of Laws 2005 No. 179, item 1485). In accordance with the abovementioned Act, the cultivation of hemp containing more than $0.2 \%$ of the psychoactive compound tetrahydrocannabinol (THC) has been prohibited. Hemp varieties containing less than $0.2 \%$ of THC in the dry plant mass, were defined as fibre crops or industrial crops (figure 1) and are approved for cultivation after obtaining permission. The cultivation of industrial hemp is defined by legal procedures due to its visual resemblance to Cannabis Indica and therefore it may facilitate local sowing of hemp with narcotic properties among industrial hemp specimens.

The period of hemp cultivation in Poland lasts about four months. The sowing season takes place in May, while the harvest period at the turn of

\section{Wstęp}

Znane niegdyś i szeroko wykorzystywane materiały produkowane $\mathrm{z}$ konopi zostały wyparte poprzez popularyzowane, zwykle importowane zamienniki, które to doprowadziły do niemal całkowitego zniknięcia upraw konopi z polskiego rolnictwa. W ostatnich latach w Polsce zauważa się wzrost zainteresowania społeczeństwa potencjałem jaki mają konopie włókniste (przemysłowe), jako roślina uprawa, której półprodukty znajdują wiele pożytecznych zastosowań. Powierzchnia upraw z roku na rok wzrasta, a w 2016 roku wyniosła około 1500 ha. Rolnicy sprzedają swoje plony, głównie nasiona, coraz częściej polskim producentom żywności, którzy produkują z nich wysokowartościową, zdrową żywność. Powiększa się również polski rynek zbytu na materiał, który dotąd stosowany był jedynie jako wyściółka dla zwierząt, lub traktowany jako odpad - paździerze konopne, które to stają coraz bardziej popularne jako materiał budowlany.

W Polsce uprawa konopi regulowana jest ustawą o przeciwdziałaniu narkomanii, która weszła w życie 24 kwietnia 1997 roku(Dz.U. 2005 nr 179 poz. 1485). Zgodnie z podaną ustawą, uprawa konopi zawierających więcej niż $0,2 \%$ substancji o działaniu psychoaktywnym - tetrahydrokanabinolu (THC) zostały zabronione. Konopie zawierające mniej niż 0,2\% THC w suchej masie ziela, określone jako włókniste lub przemysłowe (Rysunek1) są dopuszczone do uprawy po uzyskaniu pozwolenia. Procedury prawne związane z uprawą konopi włóknistych mają miejsce głównie z uwagi na wizualne podobieństwo do konopi indyjskich, co może sprzyjać miejscowym obsiewem odmian narkotycznych pośród konopi włóknistych.

Okres uprawy konopi w Polsce trwa około 4 miesiące. Wysiew odbywa się $\mathrm{w}$ maju natomiast zbiór plonów na przełomie września/ października. Surowcami, dla których obecnie uprawia się konopie

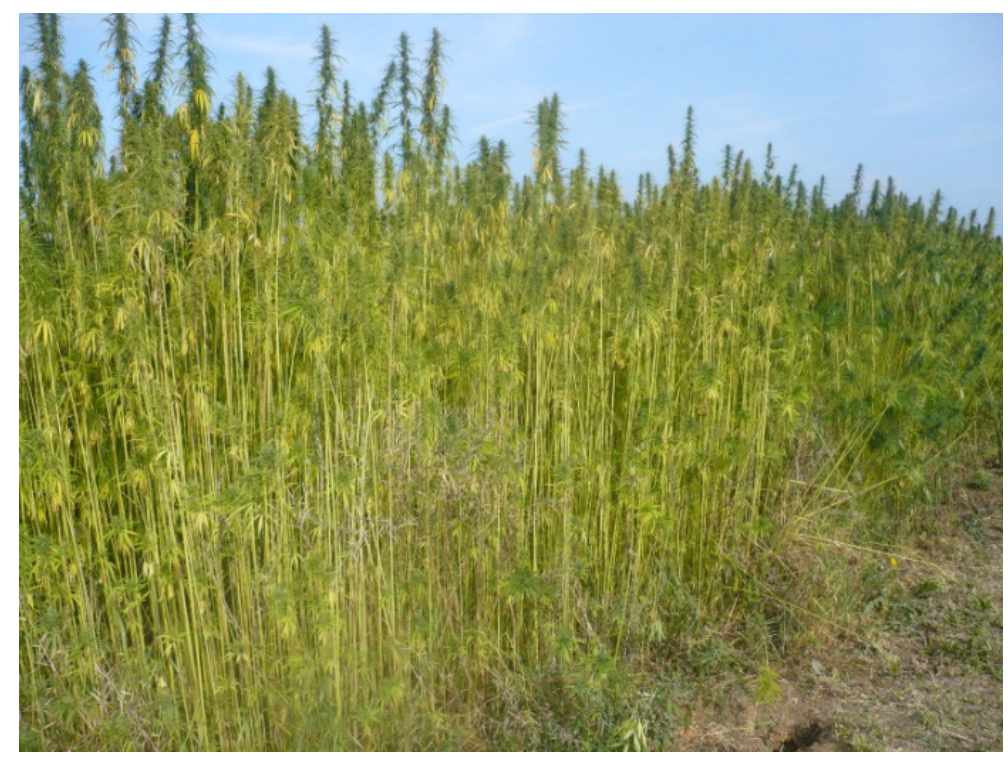

Figure 1. Industrial hemp

Rysunek 1. Konopie włókniste

Source: the authors' archive.

Źródło: archiwum autorów. 
September and October. Hemp is currently grown for raw materials like fibre, hemp seeds and ligneous parts of hemp stalks - shives. Specific certified seeds and a proper quantity of them per 1 hectare of cultivation area is used for sowing depending on their intended application. The cultivation of hemp can be ecologic, because of its low soil requirements and traces of cannabinoid content endowing it with antiseptic and fungicide properties, which makes them resistant to most diseases, thanks to which the application of fertilisers or herbicides is unnecessary. The lack of technical resources used for harvesting and processing crops for particular purposes, may restrict cultivation in many regions including Poland.

These raw materials have been used in different industries for centuries. Paper, canvas, clothes and sails were made of hemp fibre. Nowadays gradual return to the cultivation of industrial hemp and to its application in different industries may be observed. New applications of its fibre, which are used in the production of bio-composites, have been found, as a substitute of glass and carbon fibre. New applications of hemp seeds are discovered in the food and pharmaceutical industry, while hemp shives is put to use in the energy and construction industries.

\section{The application of hemp straw in the construction industry}

\section{Characteristics of hemp straw}

Hemp stalks (also known as hemp straw) consist of a core which is usually cut into pieces called shives, and fibre which is distributed longitudinally around the core.

As a result of the mechanical processing (decortication) of hemp straw it is possible to obtain fibre (figure 2) amounting to approximately 35\% and shives (figure 3 ) amounting to approximately 65\% (Capelle 1996, Gumuskaya et al. 2007). With the yield from straw harvest reaching the amount of approximately $8 \mathrm{t} / \mathrm{ha}$, it is therefore possible to obtain about 5-5.5 tonnes of shives.

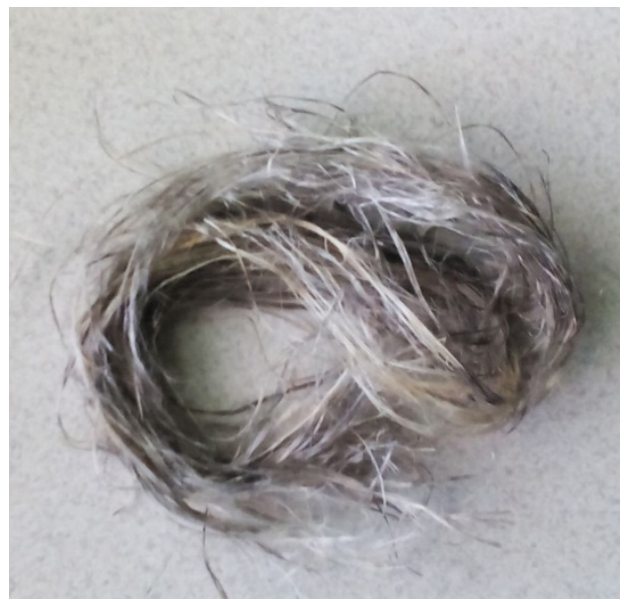

Figure 2. Hemp fibre

Rysunek 2. Włókno konopne

Source: the authors' archive.

Źródło: archiwum autorów. włókniste są włókna, siemię konopne oraz zdrewniałe części łodygi - paździerze. W zależności od przeznaczenia uprawy, stosuje się do zasiewu określone nasiona certyfikowane oraz określona ich ilość na 1 ha uprawy. Uprawa konopi może być ekologiczna, gdyż nie mają one wysokich wymagań glebowych oraz z uwagi na śladową zawartość kanabinoidów, charakteryzują się właściwościami antyseptycznymi oraz grzybobójczymi, co czyni je odpornymi na większość chorób, dzięki czemu nie jest konieczne stosowanie nawozów oraz herbicydów. Ograniczeniem upraw w wielu rejonach, w tym w Polsce, jest brak parku maszynowego do pozyskania plonów oraz ich obróbki na poszczególne cele.

Od wieków surowce te wykorzystywane są w różnych gałęziach przemysłu. Z włókien konopi produkowany był papier, płótna, ubrania oraz żagle, natomiast dziś zaobserwować można stopniowy powrót do upraw konopi włóknistych oraz wykorzystania ich $\mathrm{w}$ wielu gałęziach przemysłu. Nowe zastosowanie odnalazły włókna, które wykorzystywane są w produkcji bio-kompozytów, jako substytut włókien szklanych lub węglowych. Odkrywane są nowe zastosowania nasion konopi w przemyśle spożywczym oraz farmaceutycznym, natomiast paździerzy konopnych w przemyśle energetycznym oraz w budownictwie.

\section{Zastosowanie słomy konopnej w budownictwie}

\section{Charakterystyka słomy konopnej}

Łodyga konopi, czyli słoma składa się z rdzenia, który zwykle bywa cięty na kawałki zwane paździerzami oraz z włókna ułożonego wzdłużnie, otaczającego dookoła rdzeń.

W wyniku przerobu mechanicznego (dekortykacji) słomy konopnej możliwe jest uzyskanie włókna (Rysunek 2) w ilości około 35\% oraz paździerzy (Rysunek 3) w ilości około 65\% (Capelle 1996, Gumuskaya i in. 2007). Przy wydajności zbioru słomy konopnej w ilości ok. 8t/ha możliwe jest więc uzyskanie ok. 5-5,5 ton paździerzy.

Włókna konopne pozyskane z konopi włóknistych należą do grupy włókien łykowych łodygowych ra-

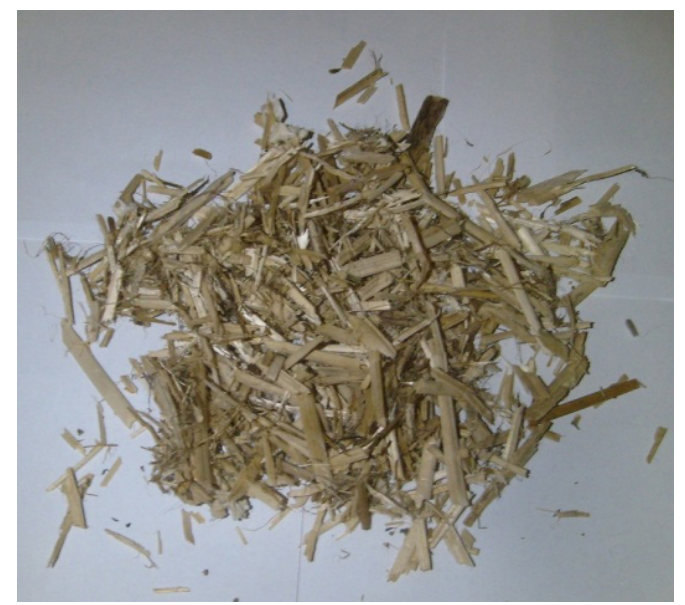

Figure 3. Hemp shives

Rysunek 3. Paździerze konopne

Source: the authors' archive.

Źródło: archiwum autorów. 
Hemp fibre obtained from industrial hemp belongs to the bast fibre group along with fibres obtained from plants such as flax, kenaf, jute, ramie, helicteres isora, stinging nettle, Spanish broom (Bogacz i in. 2012).

Bast fibres are present in two forms: elementary fibres which are separate fibres in the plant fibrous tissue and technical fibres forming a set made of thousands of elementary fibres connected by pectin, lignin and hemicellulose.

This fibre is characterized by high tensile strength and rigidity.

\section{Thermal insulation material - hemp wool}

In the construction sector both hemp fibre and shives are used. Hemp fibre is used for the production of thermal insulation material - hemp wool. The fibres are bound with rice or maize starch, and in order to increase fire resistance, a sodium carbonate additive is applied. Thermal conductivity of such insulation is $0.04 \mathrm{~W} /(\mathrm{m} \cdot \mathrm{K})$, and it does not deviate from the conventional thermal insulation parameters (www. steico.com). In addition, due to the high content of cellulose the material has the capacity to regulate the level of humidity in rooms at varying humidity conditions. Thermal insulation made of hemp fibre is capable of absorbing $20 \%$ of its own mass of moisture, while maintaining the parameters of its thermal insulation, which distinguishes it from mineral wool whose thermal insulation properties decrease drastically with increasing content of moisture in its volume (Stanwix, Sparrow 2014). This is caused by a high content of cellulose in hemp fibre - typically in the range of $57-77 \%$ (Capelle 1996). The use of hemp wool as thermal insulation is an alternative to the commonly used synthetic materials based on fossil fuels, which consume more energy and emit toxic substances in the production process. Hemp wool is produced in the form of tapes (figure 4) and boards (figure 5).

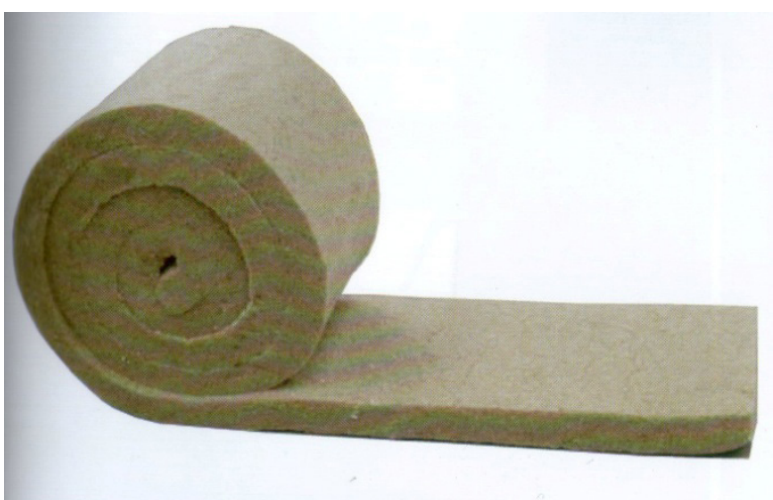

Figure 4. A thermal insulation tape from hemp fibre Rysunek 4. Taśma termoizolacyjna z włókna konopnego Source: Allin 2012.

Źródło: Allin 2012. zem z włóknami pozyskanymi z takich roślin jak len, kenaf, juta, ramia, isora, pokrzywa zwyczajna, spanishbroom (Bogacz i in. 2012).

Włókna łykowe występują w dwóch postaciach: włókien elementarnych, które są pojedynczymi włóknami w roślinnej tkance włóknistej oraz technicznych, stanowiących zespół tysięcy włókien elementarnych połączonych pektyną, ligniną i hemicelulozą.

Włókna charakteryzują się wysoką wytrzymałością na rozrywanie, rozciąganie a także wysoką sztywnością.

\section{Materiał termoizolacyjny - wełna konopna}

W sektorze budownictwa wykorzystywane sa zarówno włókna jak i paździerze konopne. Włókna konopne stosowane są do produkcji materiału termoizolacyjnego - wełny konopnej. Włókna wiązane są krochmalem ryżowym lub kukurydzianym,a w celu podwyższenia odporności na działanie ognia stosuje się dodatek sody. Współczynnik przewodności cieplnej izolacji wynosi $0,04 \mathrm{~W} / \mathrm{m} \cdot \mathrm{K}$ i nie odbiega on od parametrów konwencjonalnych izolacji termicznych (www.steico.com). Dodatkowo z uwagi na wysoką zawartość celulozy, materiał posiada zdolności regulowania poziomu wilgotności w pomieszczeniach przy zmieniających się warunkach wilgotnościowych. Izolacja termiczna z włókien konopi jest w stanie wchłonąć wilgoć w ilości $20 \%$ swojej masy przy zachowaniu parametrów dotyczących izolacyjności termicznej, co odróżnia ją od wełny mineralnej, której właściwości termoizolacyjne drastycznie spadają wraz ze wzrostem zawartości wilgoci w swej objętości (Stanwix, Sparrow 2014).Dzieje się to za przyczyną dużej zawartości celulozy we włóknie konopnym - zazwyczaj w przedziale 57-77\% (Capelle 1996). Wykorzystanie wełny konopnej jako izolacji termicznej, jest alternatywą dla powszechnie stosowanych syntetycznych materiałów opartych na paliwach kopalnych, które zużywają więcej energii oraz emitują toksyczne substancje w procesie produkcji. Wełna konopna jest produkowana w postaci taśm (Rysunek4) oraz płyt (Rysunek5).

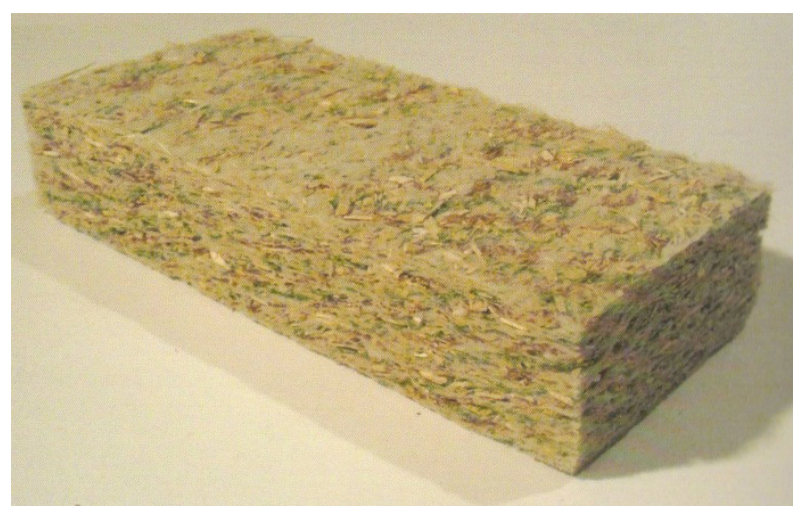

Figure 5. A thermal insulation board from hemp fibre Rysunek 5. Płyta termoizolacyjna z włókna konopnego Soruce: Allin 2012.

Źródło: Allin 2012. 


\section{Lightweight wall material}

\section{- a lime-hemp composite}

Hemp shives is used as a filler of lightweight composite based on lime binder, which is used primarily as a wall material with the function of filling the space between studs in a timber frame. Another application is in the thermal insulation of roofs and floors. The composite can be manufactured in the form of blocks (figure 6) and a monolithic mixture applied directly to the shuttering (figure 7) Fine fractions of hemp shives and fibre are also added to the lime plaster.

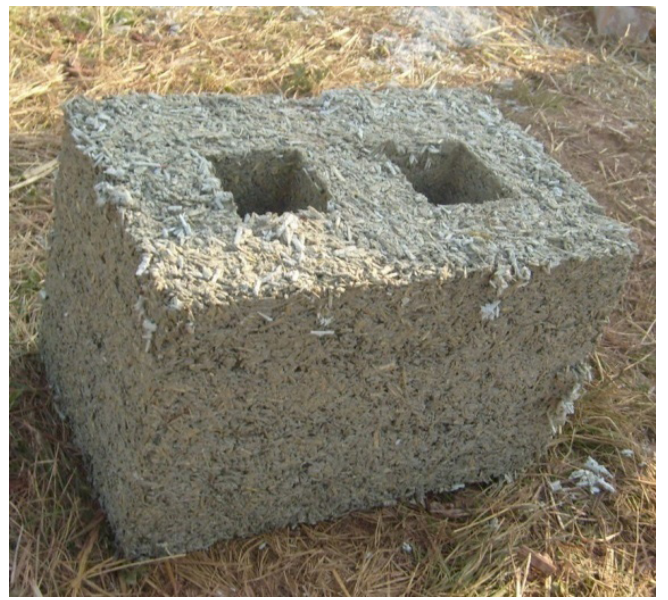

Figure 6. A prefabricated element in the form of a block of lime-hemp composite

Rysunek 6. Prefabrykat w postaci bloczka z kompozytu wapienno-konopnego

Source: the authors' archive.

Źródło: archiwum autorów.

The properties of lime-hemp composite are the subject of the authors' research. The presence of highly porous filler in the form of shives ensures low thermal conductivity of the material, which, according to the authors' research, is in the range of $0.082-0.144 \mathrm{~W} /(\mathrm{m} \cdot \mathrm{K})$, depending on the formulation, (Barnat-Hunek et al. 2015, Barnat-Hunek et al. 2016). The composite has a low density and also a good heat capacity, which ensures a heat accumulation capacity. The volume density of the composites depends on the ratio of shives and binder, and is in the range of 265.8-629.7 kg/m $\mathrm{m}^{3}$ (Barnat-Hunek et al. 2015). The diagram (figure 8) shows the relationship between the thermal conductivity and the bulk density of the composite. The dependence is not linear, the parameters depend on the quantitative configuration of the used ingredients, which are characterised by a different density and thermal conductivity.

The porous structure of hemp shives is decisive for the high porosity of the composite, which is typically about 70\% (Fic et al.2015). The hemp-lime composite has a high water-per-mass absorption ratio, which according to the author's research is from $98.5 \%$ to $150.5 \%$ (Barnat-Hunek et al. 2015). However, the capacity to diffuse of water vapour enables fairly

\section{Lekki materiał ścienny - kompozyt wapienno-konopny}

Paździerze konopne wykorzystywane są jako wypełniacz lekkiego kompozytu na bazie spoiwa wapiennego, stosowanego przede wszystkim jako materiał ścienny pełniący funkcję wypełnienia przestrzeni pomiędzy słupami w drewnianej konstrukcji szkieletowej. Innym zastosowaniem jest izolacja termiczna dachów i podłóg. Kompozyt produkowany może być w postaci bloczków (Rysunek6) oraz mieszanki monolitycznej aplikowanej bezpośrednio w deskowanie (Rysunek7). Drobne frakcje paździerzy konopnych a także włókien dodawane są również do tynków wapiennych.

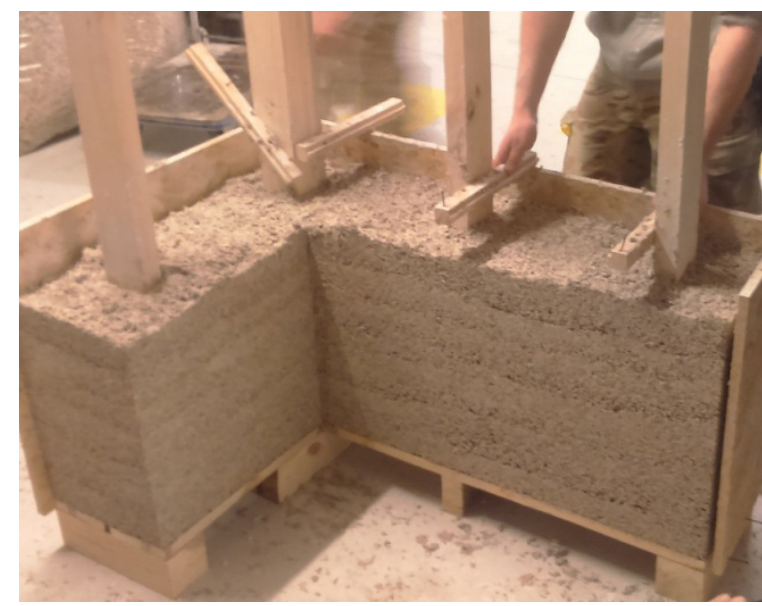

Figure 7. The mixture of lime-hemp composite placed in the wall shuttering

Rysunek 7. Mieszanka kompozytu wapienno konopnego umieszczona w deskowaniu ściennym Source: the authors' archive.

Źródło: archiwum autorów.

Właściwości kompozytu wapienno-konopnego sa przedmiotem badań autorów artykułu. Obecność wysoce porowatego wypełniacza w postaci paździerzy zapewnia niską przewodność cieplną materiału, która wg badań własnych, w zależności od receptury mieści się w przedziale 0.082-0.144 W/(m·K) (Barnat-Hunek i in. 2015, Barnat-Hunek i in. 2016).Kompozyt charakteryzuje się niska gęstościa a zarazem dobrą pojemnością cieplną, która zapewnia zdolności akumulowania ciepła. Gęstość objętościowa kompozytów zależy od proporcji paździerzy do spoiwa i mieści się w przedziale $265.8-629.7 \mathrm{~kg} / \mathrm{m}^{3}$ (Barnat-Hunek i in. 2015). Na wykresie (Rysunek 8) przedstawiono zależność przewodności cieplnej od gęstości objętościowej kompozytu. Zależność nie jest liniowa, parametry zależą od konfiguracji ilościowej zastosowanych składników, które charakteryzują się różną gęstością i przewodnością cieplną.

Porowata struktura paździerzy konopnych decyduje o wysokiej porowatości kompozytu, która wynosi zwykle około 70\% (Fic i in. 2015). Kompozyt wapienno konopny charakteryzuje się wysoką nasiąkliwością wagowa, która jak wynika z badań własnych wynosi od $98.5 \%$ do $150.5 \%$ (Barnat-Hunek i in. 2015). Jednak zdolność do dyfuzji pary wodnej 
quick drying of the material to the humidity level of the surroundings, after removing the source of moisture. The diagram (figure 9) shows the relationship between the water-per-mass absorption ratio and the bulk density of the composite. The increase in density is connected with an increase in the binder content, resulting in greater tightness of the composite, and thereby in decreased absorption. umożliwia dość szybkie wysychanie materiału do stanu otoczenia po odcięciu źródła zawilgocenia. $\mathrm{Na}$ wykresie (Rysunek9) pokazano zależność nasiąkliwości wagowej od gęstości objętościowej kompozytu. Wzrost gęstości związany jest ze wzrostem zawartości spoiwa, co powoduje większą szczelność kompozytu, a tym samym spadek nasiąkliwości.

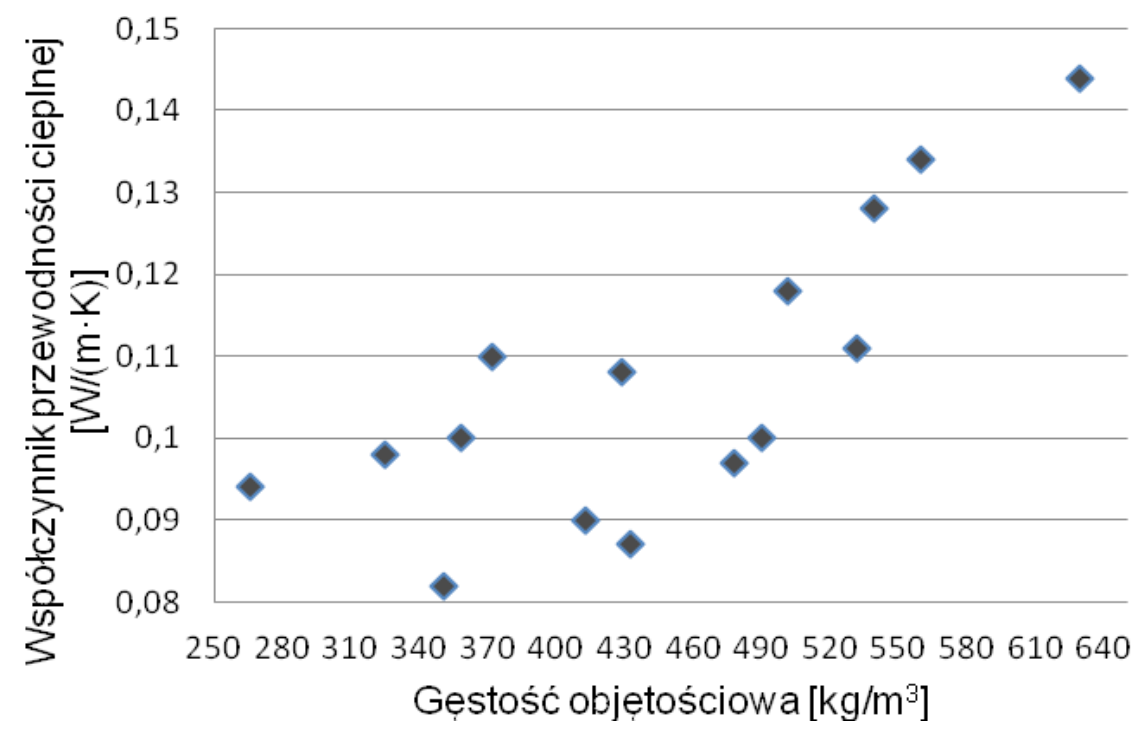

Legend: Współczynnik przewodności cieplnej [W/(m·K)] - Thermal conductivity coefficient [W/(m·K)] Gęstość objętościowa $\left[\mathrm{kg} / \mathrm{m}^{3}\right]$ - bulk density $\left[\mathrm{kg} / \mathrm{m}^{3}\right]$

Figure 8. The dependency of thermal conductivity coefficient of the composite and its bulk density Rysunek 8. Zależność współczynnika przewodności cieplnej kompozytu od jego gęstości objętościowej Source: the authors' archive based on Barnat-Hunek et al. 2015, Barnat-Hunek et al. 2016.

Źródło: archiwum autorów na podstawie Barnat-Hunek i in. 2015, Barnat-Hunek i in. 2016.

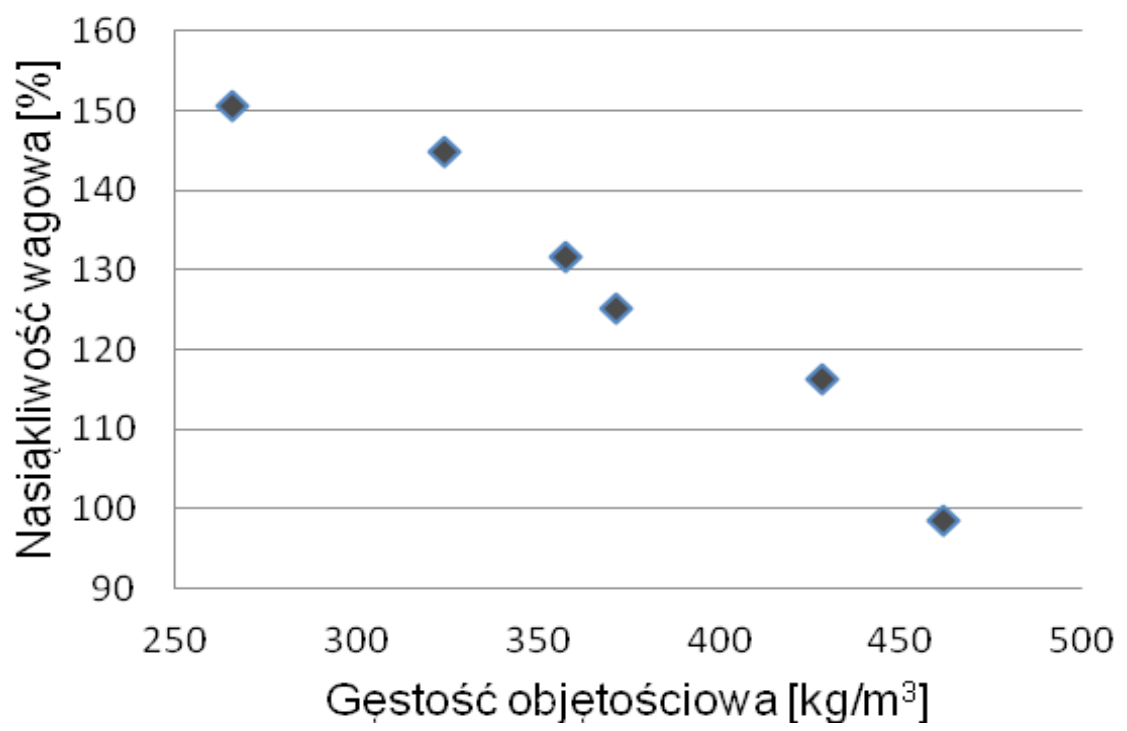

Legend: Nasiq̨kliwość wagowa [\%] - Water absorption by weight [\%] Gęstość objętościowa $\left[\mathrm{kg} / \mathrm{m}^{3}\right]$ - bulk density $\left[\mathrm{kg} / \mathrm{m}^{3}\right]$

Figure 9. The relationship between the water-per-mass absorption ratio and the volume density of the composite Rysunek 9. Zależność nasiąkliwości wagowej od gęstości objętościowej kompozytu Source: the authors' archive based on the Barnat-Hunek et al. 2015.

Źródło: archiwum autorów na podstawie Barnat-Hunek i in. 2015. 
The presented composite shows a positive environmental impact. Industrial hemp exhibits a high capacity to absorb carbon dioxide through photosynthesis, collecting it in their tissues in the form of carbon. 1 ton of hemp shives can store 1.8 tonnes of carbon dioxide during their growth phase. According to an exemplary formulation of the proportion of the binder to hemp shives, by weight, being 2: 1 per $1 \mathrm{~m}^{3}$ of the walls made of lime-hemp composite, $220 \mathrm{~kg}$ of lime binder and $110 \mathrm{~kg}$ of hemp shives are needed (Bevan, Wooley 2010). On the example of the mixture in Table 1 we have presented the eco-balance of the emission and absorption of carbon dioxide during the production of the main materials which the composite is composed of (hydrated lime and shives).
Prezentowany kompozyt wykazuje pozytywny wpływ środowiskowy. Konopie włókniste charakteryzują się wysoką zdolnością pochłaniania dwutlenku węgla w procesie fotosyntezy odkładając go w swych tkankach w postaci węgla. 1 tona paździerzy konopnych jest w stanie zmagazynować $\mathrm{w}$ okresie wzrostu 1,8 tony dwutlenku węgla. Według przykładowej receptury o proporcji spoiwa do paździerzy konopnych 2:1 wagowo, na $1 \mathrm{~m}^{3}$ ściany wykonanej z kompozytu wapienno konopnego potrzeba $220 \mathrm{~kg}$ spoiwa wapiennego oraz 110 kg paździerzy konopnych (Bevan, Wooley 2010). Na przykładzie tej mieszanki w tablicy 1 podano eko-bilans emisji oraz pochłaniania dwutlenku węgla w czasie produkcji głównych materiałów wchodzących w skład kompozytu (wapno hydratyzowane oraz paździerze konopne).

Table 1. The balance of absorption and emission of carbon dioxide in the lime-hemp composite components (Bevan, Wooley 2010)

Tabela 1. Bilans pochłaniania i emisji dwutlenku węgla przez składniki kompozytu wapiennego-konopnego (Bevan, Wooley 2010)

\begin{tabular}{|c|c|}
\hline $\begin{array}{l}\text { Ingredients of } 1 \mathrm{~m}^{3} \text { of a composite wall/ } \\
\text { Składniki } 1 \mathrm{~m}^{3} \text { ściany z kompozytu }\end{array}$ & $\begin{array}{l}\text { The absorption/emission of } \mathrm{CO}_{2 /} \\
\text { Absorpcja/ emisja } \mathrm{CO}_{2}\end{array}$ \\
\hline $\begin{array}{l}110 \text { kg of hemp shives/ } \\
110 \text { kg paździerzy konopnych }\end{array}$ & $\begin{array}{l}\text { The absorption of } \mathrm{CO}_{2}-202 \mathrm{~kg} / \\
\text { Absorpcja } \mathrm{CO}_{2}-202 \mathrm{~kg}\end{array}$ \\
\hline $\begin{array}{l}220 \mathrm{~kg} \text { of hydrated lime/ } \\
220 \mathrm{~kg} \text { wapna hydratyzowanego }\end{array}$ & $\begin{array}{l}\text { The emission of } \mathrm{CO}_{2}-94 \mathrm{~kg} / \\
\text { Emisja } \mathrm{CO}_{2}-94 \mathrm{~kg}\end{array}$ \\
\hline Balance & $108 \mathrm{~kg} \mathrm{CO}_{2} / \mathrm{m}^{3}$ \\
\hline
\end{tabular}

Due to the presence of lime binder, the composite is an alkaline environment, resistant to the growth of mould. The conducted research, consisting in the implantation of microorganisms resistant to an alkaline environment into the composite, demonstrated, that the lack of nutrients in the composite also contributes to a low risk of mould
Z uwagi na obecność spoiwa wapiennego, kompozyt jest środowiskiem alkalicznym, odpornym na rozwój pleśni. Przeprowadzone badania polegające na wszczepieniu mikroorganizmów odpornych na środowisko alkaliczne w kompozyt dowiodły z kolei, że brak składników odżywczych w kompozycie również decyduje o małym ryzyku pojawienia się

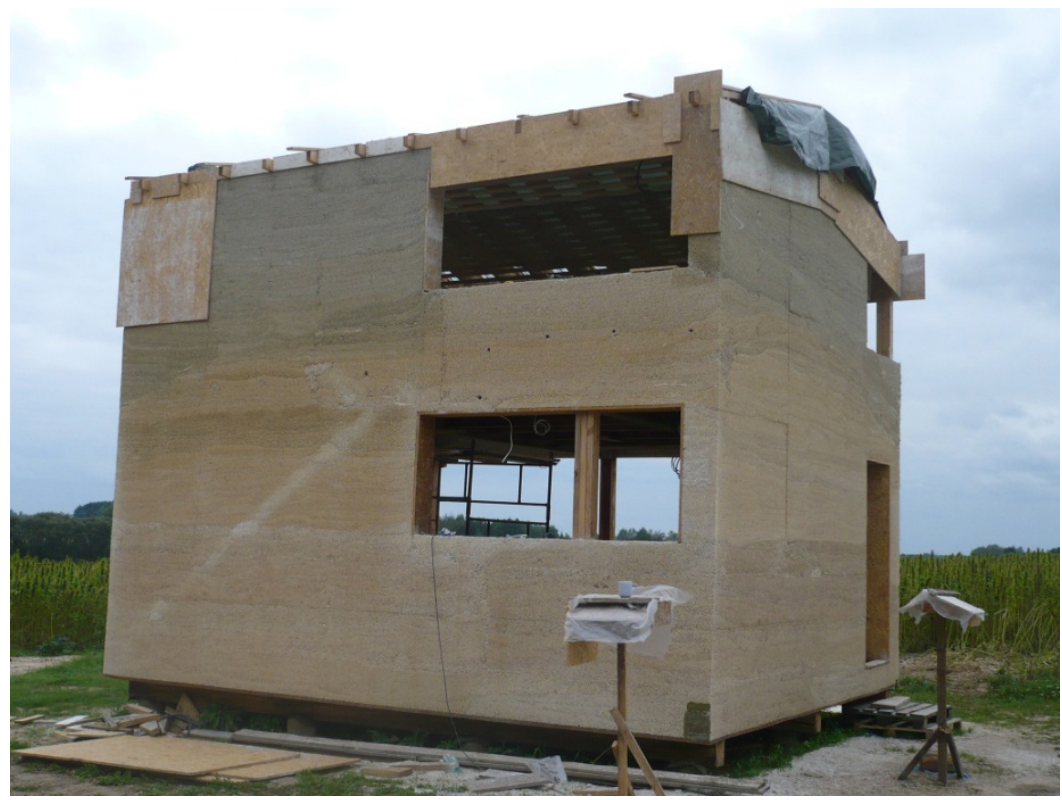

Figure 10. Erecting the first house in Poland completely insulated with hemp

Rysunek 10. Realizacja pierwszego w Polsce domu całkowicie izolowanego konopiami Source: the authors' archive.

Źródło: archiwum autorów. 
development on the surface of the composite - during the research they died after a few weeks under natural conditions (Bevan, Wooley 2010). Lime also ensures fire resistance of the material - shives should be carefully covered with a layer of lime binder.

In 2016 in Podlaskie Province the first building completely insulated with lime-hemp composite in Poland was built (figure 10). For the construction, the shives obtained from local hemp cultivation (varieties: Białobrzeskie and Finola) and a binder based on hydrated lime with hydraulic additives were used. Currently, the building is used as livesize model for the studies of physical and mechanical characteristics of the embedded materials.

\section{Other applications of industrial hemp}

\section{Hemp seeds}

The composition of industrial hemp seeds (figure 11) includes $20-25 \%$ of protein, $20-30 \%$ carbohydrates, $25-35 \%$ oil, $10-15 \%$ of insoluble dietary fibre and important minerals (Sacilik et al. 2003). Hempseed oil has a high content of unsaturated fatty acids (about 75\% of oil components), such as oleic acid, linoleic acid and linolenic acid, and gammalinolenic acid in the proportions most suitable for the human body - 3: 1, respectively - linoleic acid: linolenic acid (Rausch 1995). Gamma-linolenic acid contained in hempseed oil regulates the level of blood lipids, thereby preventing atherosclerosis, heart attacks and strokes. The deficiency of fatty acids also leads to skin diseases. In hempseed oil one can also be find a large amount of vitamin $\mathrm{K}$, involved in the synthesis of important proteins and enzymes. Vitamin K ensures proper blood coagulability and stops bleeding; it has antifungal, antibacterial, antiinflammatory, analgesic properties and participates grzybów pleśniowych na powierzchni kompozytu podczas badania obumarły one po kilku tygodniach w naturalnych warunkach (Bevan, Wooley 2010). Wapno zapewnia również ognioodporność materiału - paździerze powinny być dokładnie pokryte warstwą spoiwa wapiennego.

W 2016 roku został wybudowany w województwie podlaskim pierwszy w Polsce budynek całkowicie izolowany kompozytem wapienno-konopnym (Rysunek10). Do budowy wykorzystano paździerze pozyskane z lokalnych upraw konopi(odmiany: Białobrzeskie i Finola) oraz spoiwo oparte na wapnie hydratyzowanym $\mathrm{z}$ dodatkami hydraulicznymi. Obecnie na budynku jako modelu w skali rzeczywistej prowadzone są badania charakterystyk fizyko-mechanicznych wbudowanych materiałów.

\section{Inne zastosowania konopi włóknistej}

\section{Siemię konopne}

Skład nasion konopi włóknistych (Rysunek11) stanowią w ilości 20-25\% białka, 20-30\% węglowodany, 25-35\% olej, $10-15 \%$ błonnik nierozpuszczalny oraz cenne minerały (Sacilik i in. 2003). Olej konopny charakteryzuje się wysoką zawartością nienasyconych kwasów tłuszczowych (około 75\% składników oleju) takich jak kwas oleinowy, linolowy i linolenowy, jak również gamma-linolenowy, w proporcjach najbardziej odpowiednich dla organizmu ludzkiego - 3:1, odpowiednio-kwas linolowy: linolenowy (Rausch 1995). Kwas gamma-linolenowy zawarty w oleju reguluje poziom lipidów we krwi, zapobiegając tym samym miażdżycy, zawałom serca oraz udarom. Niedobór kwasów tłuszczonych prowadzi również do chorób skóry. W oleju konopnych zawarta jest również duża ilość witaminy K, biorącej udział w syntezie ważnych białek i enzymów. Witamina K zapewnia krzepliwość krwi i powoduje zatrzymanie krwawienia, ma właściwości przeciwgrzybiczne, antybakteryjne, przeciwza-

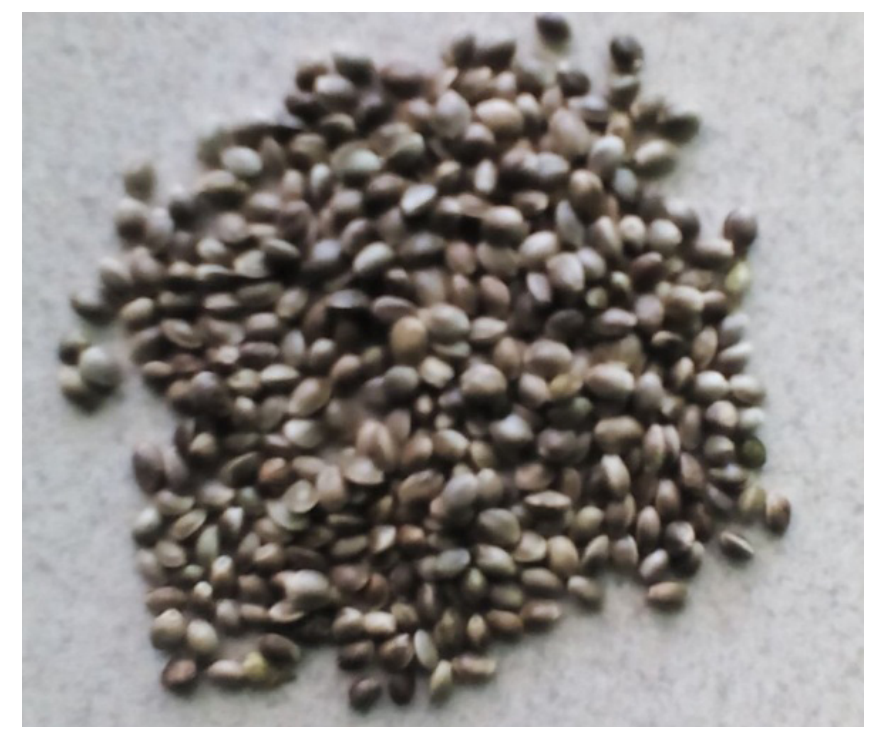

Figure 11. Industrial hemp seeds

Rysunek 11. Nasiona konopi włóknistych

Source: the authors' archive.

Źródło: archiwum autorów. 
in the formation of bone tissue. Hempseed oil, due to its structure is not suitable for frying - then it loses its therapeutic properties. Hemp seeds can be eaten unprocessed, raw. They can also be used for the production of other food products, e.g. flour, pasta and butter.

The properties of hempseed oil have also found application in the pharmaceutical and cosmetics industry. It is used in medicines alleviating skin burns, facilitating wound healing and also in cosmetics for dry and sensitive skin (soaps, shampoos, hair conditioners, creams). In alternative medicine, hemp oil is an ingredient of the products used for aromatherapy and massages. Due to the toxicity concerns, hemp products used in cosmetics must contain less than 10 parts per million of the psychoactive substance THC (www.spliff.pl).

Hempseed oil extracted from the seeds sown in contaminated areas (industrial hemp is also used for the reclamation of contaminated and former mining terrain), due to its capability of reducing the trace content of heavy metals such as cadmium, lead, zinc, copper (Linger et al. 2003)) is tested for the production of heavy oil by adding methanol in the amount of $15 \%$ by volume. The combustion of such oil produces approximately $70 \%$ less soot than in the case of petroleum-based oil (www.bio-based. eu). Heavy oil based on hempseed oil has a low cloud point and low kinematic viscosity. These properties are the reason of the better efficiency of this fuel at low temperatures (Li et al. 2010).

\section{Hemp straw}

Until the end of the 19th century, industrial hemp was widely used in the global production of paper, because paper was made of old, damaged sails, clothes, bedsheets, which were made mostly from hemp and flax. The raw material for the production of paper is both fibre and shives. The cellulose constitutes 57$77 \%$ of fibre composition (Capelle 1996) and 40-48\% of hemp shives (Jaldon-Garcia et al. 1998).

In the late 30's of the 20th century in the United States the technology of the mass production of paper from hemp cellulose was improved. However, after passing an act of law in 1937, prohibiting the cultivation of hemp, the industry using any intermediate hemp product was effectively banned, and hemp cellulose for paper production was almost completely replaced by wood. The process of paper production and its whitening involves the removal of the third - in terms of quantity - component of wood (next to cellulose and hemicellulose) - lignin, which is a binder that ensures the density of the wood cell structure. There is about $21-27 \%$ of it in wood (Demirbaş 1997), whereas in hemp fibre - about 5-9\% (Capelle 1996), and in the fresh, green fibre - about 4\% (Jaldon-Garcia et al. 1998). The destruction of lignin for the purpose of paper bleaching causes emission of toxic substances (dioxins), so a small amount of lignin in hemp requires a minimal usage of bleaching agents. Paper palne, przeciwbólowe oraz bierze udział $\mathrm{w}$ formowaniu tkanki kostnej. Olej konopny, ze względu na swoją strukturę nie nadaje się do smażenia - traci wówczas swoje właściwości zdrowotne. Ziarna konopi można spożywać również nieprzerobione, surowe. Mogą być też wykorzystywane do produkcji innych produktów spożywczych np. makki, makaronu oraz masła.

Właściwości oleju konopnego odnalazły zastosowanie również $\mathrm{w}$ przemyśle farmaceutycznym oraz w branży kosmetycznej. Wykorzystywany jest w lekach łagodzących oparzenia skóry, ułatwiających gojenie ran a także w kosmetykach do skóry suchej i wrażliwej (mydła, szampony, odżywki do włosów, kremy). W medycynie alternaty wnej olej z konopi zawarty jest $\mathrm{w}$ produktach stosowanych $\mathrm{w}$ aromaterapii oraz masażach. Z uwagi na toksyczność, produkt konopny wykorzystywany w kosmetyce musi zawierać mniej niż 10 części na milion substancji psychoaktywnej THC (www.spliff.pl).

Olej konopny pozyskiwany z nasion roślin wysianych na terenach skażonych (konopie włókniste wykorzystywane są również do rekultywacji terenów skażonych, pogórniczych, z uwagi na możliwość redukcji zawartości śladów metali ciężkich, takich jak kadm, ołów, cynk, miedź (Linger i in. 2003)) testowany jest do produkcji olejów napędowych z dodatkiem metanolu w ilości 15\% objętościowo. Spalanie takiego oleju produkuje o około $70 \%$ mniej sadzy niż w przypadku oleju na bazie ropy naftowej (www.bio-based. eu). Olej napędowy na bazie oleju konopnego posiada niską temperaturę mętnienia i niską lepkość kinematyczną. Te właściwości przyczają się lepszej efektywności paliwa w niskich temperaturach (Li i in. 2010).

\section{Słoma konopna}

Do końca XIX w.konopie przemysłowe były szeroko wykorzystywana w światowej produkcji papieru, gdyż produkowano papier ze starych, zniszczonych żagli, ubrań, prześcieradeł, które wykonywane były głównie z konopi oraz lnu. Surowcem do produkcji papieru sa zarówno włókna jak i paździerze. Celuloza stanowi 5777\% składu włókna (Capelle 1996) oraz 40-48\% składu paździerzy konopnych (Garcia-Jaldon i in. 1998).

Pod koniec lat 30-tych XX wieku w Stanach Zjednoczonych udoskonalona została technologia masowej produkcji papieru z celulozy konopnej, jednak po uchwaleniu w 1937 r. w USA ustawy zakazującej uprawy konopi, przemysł wykorzystujący jakikolwiek półprodukt konopny został skutecznie zdelegalizowany a celuloza konopna do produkcji papieru została niemal całkowicie zastąpiona drewnem. Proces produkcji papieru oraz jego wybielenia wymaga usunięcia trzeciego pod względem ilościowym składnika drewna (obok celulozy i hemicelulozy) - ligniny, będącej lepiszczem zapewniającym zwartość struktury komórek drewna. W drewnie znajduje się go około 21-27\% (Demirbas 1997), natomiast we włóknach konopi około 5-9\% (Capelle 1996) a w świeżym, zielonym włóknie około 4\% (Garcia-Jaldon i in. 1998). Niszczenie ligniny w celu wybielenia papieru wiąże się z odprowadzaniem toksycznych substancji (dioksyny), więc mała ilość ligniny w konopiach wymaga minimalnego zużycia substancji wybielających. Papier pochodzący z ko- 
made of hemp can be bleached with agents based on the active oxygen, which is used - among other things - in hair lightening. In addition, from the same area of hemp and trees cultivation more hemp cellulose may be obtained. The hemp yield collected from one hectare of a plantation can produce a four times larger amount of paper pulp than trees grown on the same area. It should be also emphasized that hemp is an annual plant, and its growth lasts four months as opposed to many years needed for the growth of trees.

Like other fibre crops (e.g. common flax, cotton), industrial hemp is used to produce fabrics. For centuries clothes that do not cause skin irritations and allergic reactions have been produced from hemp. The ability of hemp fibre to regulate the humidity level protects the skin from changing thermal and humidity conditions. This fibre is stronger in comparison with cotton currently prevailing in the clothing industry. The cultivation of cotton requires far more water compared to growing hemp and necessitates the use of herbicides and pesticides, which limits its natural, organic character.

Hemp cellulose is also used as a substitute for synthetic materials used in the production of plastics, e.g. polyethylene composites reinforced with hemp fibre (Singh et al. 2014). It is applied in manufacturing elements of car interior, e.g. door panels, dashboards, as well as the body and wings. Hemp fibre in this case can be used in composites as a substitute for glass fibre and carbon fibre, which are more expensive and whose production or reprocessing puts pressure on the environment because it requires high temperature, resulting in a substantial energy consumption of these materials. According to European data for 2012, the use of hemp nopi można wybielać również wybielaczami na bazie aktywnego tlenu, wykorzystywanego m.in. przy rozjaśnianiu włosów. Dodatkowo z tej samej powierzchni uprawy konopi i drzew pozyskać można więcej celulozy konopnej. Konopie zebrane z jednego hektara upraw umożliwiają wytworzenie około czterokrotnie więcej masy papierowej niż drzewa z takiej samej powierzchni uprawy. Podkreślić należy również fakt, iż konopie są roślinami jednorocznymi, a ich wzrost trwa 4 miesiące w przeciwieństwie do wieloletniego okresu wzrostu drzew.

Podobnie jak inne rośliny włókniste (np. len zwyczajny, bawełna), konopie włókniste wykorzystywane są do produkcji tkanin. Z włókien konopi od wieków produkowane były ubrania, które nie powoduja podrażnień skóry oraz reakcji alergicznych. Zdolność włókna konopnego do regulowania poziomu wilgotności chroni skórę przed zmieniającymi się warunkami termicznymi oraz wilgotnościowymi. Włókna są mocniejsze $\mathrm{w}$ porównaniu $\mathrm{z}$ dominującymi obecnie w przemyśle odzieżowym bawełnianymi. Uprawa bawełny wymaga zdecydowanie więcej wody w porównaniu do upraw konopi, a także konieczność stosowania herbicydów i pestycydów co ogranicza jej naturalny, organiczny charakter.

Celuloza konopna jest również wykorzystywana jako substytut materiałów syntetycznych wykorzystywanych w produkcji tworzyw sztucznych, np. kompozy tów polietylenowych zbrojonych włóknami konopnymi (Singh i in. 2014). Stosowana jest przy wykonywaniu elementów wnętrza samochodu, np. paneli drzwiowych, desek rozdzielczych ale również karoserii oraz błotników. Włókna konopne w tym przypadku mogą być stosowane w kompozytach jako zamiennik włókien szklanych i węglowych, które są droższe, a ich produkcja oraz utylizacja obciąża śro-

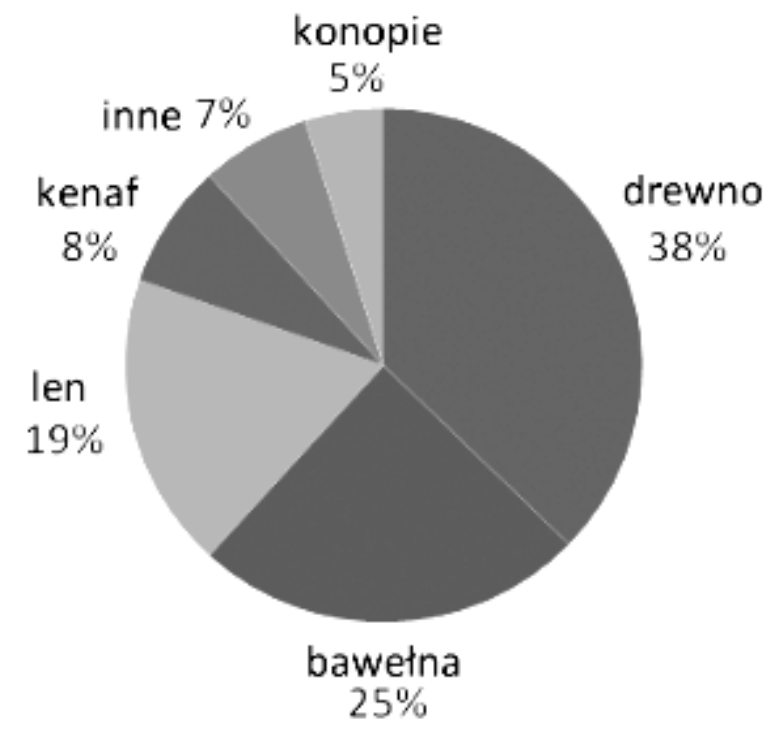

Legend: konopie - hemp; drewno -wood; bawetna - cotton; len - flax; kenaf - hibiscus cannabinus; inne - other

Figure 12. Consumption of natural fibres in the production of composites. Data on the automotive industry in Europe, 2012 Rysunek 12. Zużycie włókien naturalnych do produkcji kompozy tów. Dane dotyczące przemysłu samochodowego w Europie, 2012 r.

Source: Barton et al. 2014.

Źródło: Barton i in. 2014. 
in the automotive industry accounted for the lowest percentage share among the materials of plant origin (figure 12), the main reason for this being the smallest resources of raw hemp material (Barton et al. 2014).

Bio-composite plastics can be used in the production of many daily necessities. The presence of cellulose, hemicellulose and lignin in hemp fibre composition contributes to the thermal stability of this raw material. In the processes of manufacturing biocomposites, whereby the temperature exceeds $200^{\circ} \mathrm{C}$, thermal degradation of plant material occurs, leading to deterioration of the mechanical properties of this material. Therefore, the matrix of composites developed with the use of organic materials is mainly constructed with thermoplastic polymers which are processed in acceptable temperature ranges (Barton et al. 2014).

Hemp pulp as a substitute for wood is also used for the production of transparent cellulose foil (cellophane), consisting of about $75 \%$ cellulose and $18 \%$ of softening agent. The most important feature, which is the fundamental difference between cellulose foil and plastic foil is the biodegradability and possibility of composting the former. The chemical components of cellophane are carbon, hydrogen and oxygen (Campo et al. 2010).

Hemp fibre, due to its durability and resistance, has been used to make twisted or braided ropes and strings (figure 13). Hemp fibre, as well as flax fibre, is used in hydraulics, with an addition of paste, to seal connections in plumbing by winding it around threaded connections, ensuring a complete sealing after tightening as well as pipe wrapping (figure 14).

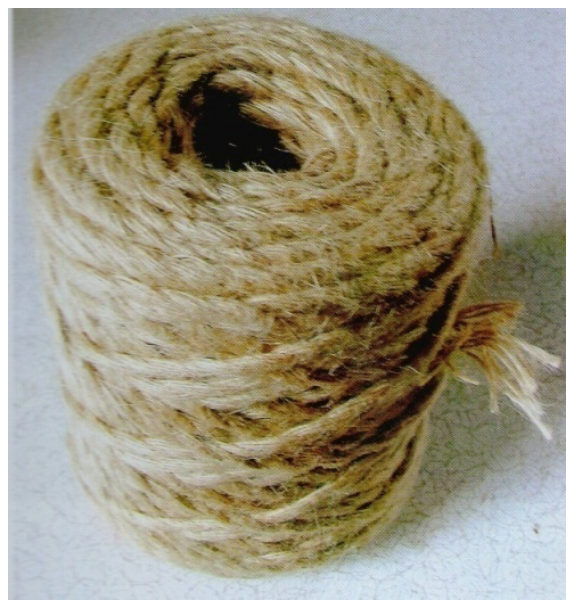

Figure 13. Hemp fibre rope

Rysunek 13. Sznur z włókien konopnych Source: Allin 2012.

Źródło: Allin 2012 dowisko, gdyż wymaga wysokiej temperatury, co wiąże się ze znaczną energochłonnością surowca. Według danych europejskich na rok 2012, wykorzystanie konopi w przemyśle samochodowym stanowiło najmniejszy udział procentowy wśród materiałów pochodzenia roślinnego (Rysunek 12), czego główną przyczyną są najmniejsze zasoby surowców konopnych (Barton i in. 2014).

Bio- kompozytowe tworzywa sztuczne moga znaleźć zastosowanie w produkcji wielu przedmiotów codziennego użytku. Obecność celulozy, hemicelulozy i ligniny w składzie włókien konopi wpływa na wpływa na trwałość termiczna tych surowców. W procesach wytwarzania biokompozytów, w których temperatura przekracza $200^{\circ} \mathrm{C}$, dochodzi do termicznej degradacji surowców roślinnych, co wpływa na pogorszenie właściwości mechanicznych materiału. W związku z tym, na osnowę kompozytów powstałych z udziałem surowców organicznych wykorzystuje się przede wszystkim polimery termoplastyczne, które przetwarzane są w akceptowalnych temperaturach (Barton i in. 2014).

Masa celulozowa z konopi, jako zamiennik drewna, wykorzystywana jest również do produkcji przezroczystej folii celulozowej (celofanu), składającej się z około $75 \%$ celulozy oraz $18 \%$ środka zmiękczającego. Cechą najbardziej istotną i stanowiącą podstawową różnicę pomiędzy folią celulozową a folią z tworzyw sztucznych jest biodegradowalność i możliwość kompostowania tej pierwszej. Składnikami chemicznymi celofanu są węgiel, wodór i tlen (Campo i in. 2010).

Włókno konopne ze względu na swoją trwałość oraz wytrzymałość stosowane było do produkcji lin skręcanych lub plecionych oraz sznurów (Rysunek13). Włókna konopne, jak również lniane $\mathrm{z}$ dodatkiem pasty stosowane są $\mathrm{w}$ hydraulice do uszczelniania złącz przewodów rurowych poprzez owijanie połączeń gwintowanych, zapewniając całkowite uszczelnienie po dokręceniu, a także jako otulina rur (Rysunek 14).

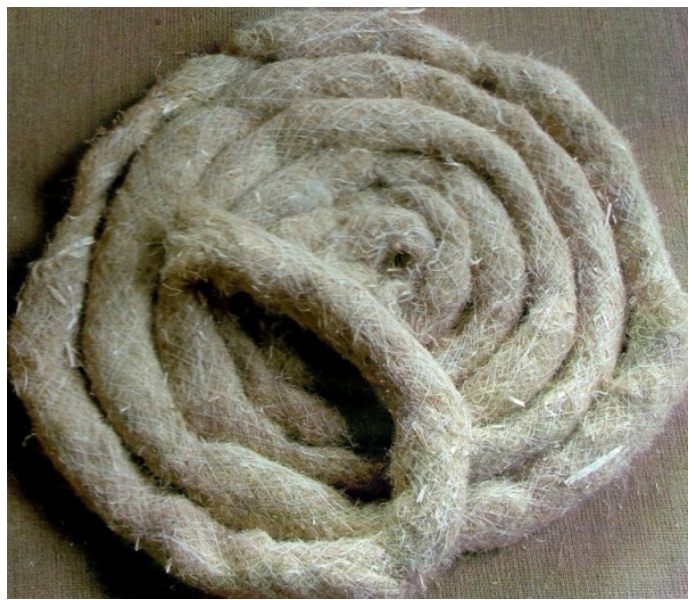

Figure 14. Pipe wrapping made of hemp fibre Rysunek 14. Otulina rur wykonana z włókien konopnych

Source: Allin 2012

Źródło: Allin 2012. 
Shives as a completely natural, biodegradable, absorbing material is also used as a bedding for livestock or as a fertilizer in the form of compost.

The biomass obtained from hemp is an efficient (stem growth of about $50 \mathrm{~cm}$ per month (Poisa et al. 2010) and valuable energy resource. For this purpose, the most desirable product is shives obtained during the processing of hemp straw. The energy value of industrial hemp exceeds $18 \mathrm{MJ} / \mathrm{kg}$. For comparison, the calorific value of wood is $17 \mathrm{MJ} /$ $\mathrm{kg}$, and additionally, the cost of obtaining the final energy resource is higher than in the case of hemp. $\mathrm{CO}_{2}$ emission from burning hemp biomass is about 0,8 $\mathrm{kg} \mathrm{CO}_{2} / \mathrm{kg}$, while $\mathrm{CO}$ does not exceed $0.15 \mathrm{~kg} \mathrm{CO} / \mathrm{kg}$ of raw material mass (Grabowska, et al. 2007). Due to the low density of shives and thus its large volume, it is processed into briquettes and pellets with the purpose of storage and usage facilitation. Hemp shives briquetting does not require the use of chemical agents because pieces of shives stick together thanks to natural chemical substances contained therein and high pressure. In Figure 15 the energy value of selected materials is presented.
Paździerze, jako całkowicie naturalny materiał chłonny ulegający biodegradacji, stosowanesą również jako ściółka dla zwierząt lub jako nawóz w postaci kompostu.

Uzyskiwana biomasa $\mathrm{z}$ konopi jest wydajnym (przyrost łodygi rośliny około $50 \mathrm{~cm}$ na miesiąc (Poisa $i$ in. 2010) i cennym surowcem energetycznym. Najbardziej pożądane do tego celu są powstające w czasie przerobu słomy konopnejpaździerze. Wartość energetyczna konopi włóknistych przekracza $18 \mathrm{MJ} / \mathrm{kg}$. Dla porównania wartość kaloryczna drewna wynosi $17 \mathrm{MJ} / \mathrm{kg}$, a dodatkowo koszt pozyskania gotowego surowca energetycznego jest wyższa niż w przypadku konopi. Emisja $\mathrm{CO}_{2}$ podczas spalania biomasy konopnej wynosi około $0,8 \mathrm{~kg} \mathrm{CO}_{2} / \mathrm{kg}$, natomiast $\mathrm{CO}$ nie przekracza $0,15 \mathrm{~kg} \mathrm{CO} / \mathrm{kg}$ masy surowca(Grabowska i in. 2007). Ze względu na niską gęstość paździerzy a tym samym dużą objętość, produkowane sa $\mathrm{z}$ nich brykiety oraz pelety mające na celu ułatwienie składowania, a także stosowania. Brykietyzacja paździerzy konopnych nie wymaga stosowania środków chemicznych, gdyż kawałki paździerzy sklejają się ze sobą za pomocą zawartych $\mathrm{w}$ nich naturalnych substancji chemicznych oraz wysokiego ciśnienia. Na rysunku 15 przedstawiono wartość energetyczną wybranych materiałów.

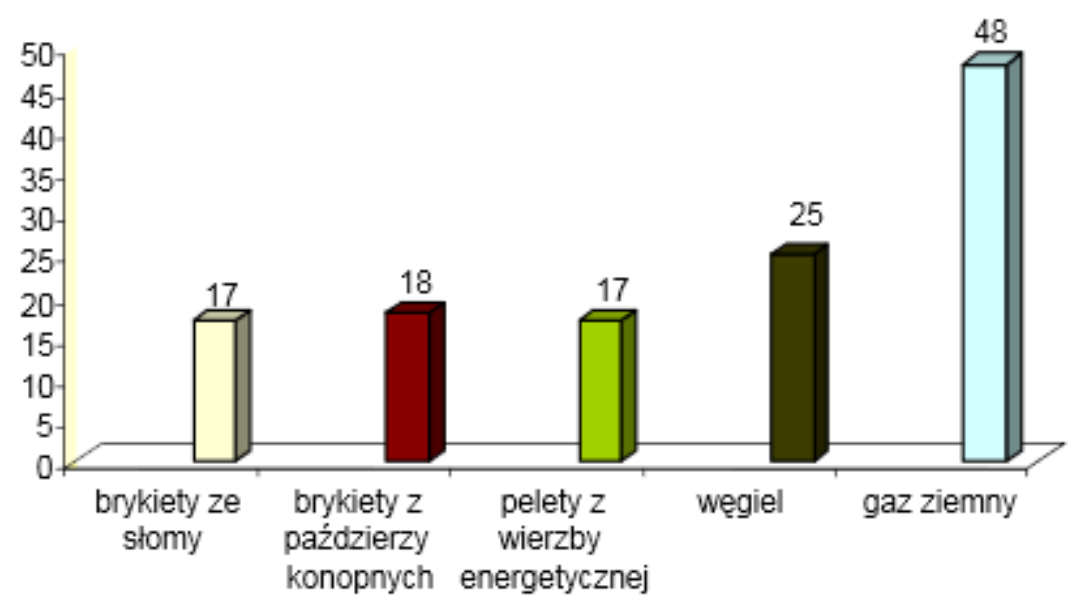

Legend: brykiety ze słomy - straw briquettes; brykiety z paździerzy konopnych - hemp shives briquettes; palety z wierzby energetycznej - pallets made from energy-crop willow; węgiel - coal; gaz ziemny - natural gas

Figure 15. The energy value of selected materials, $\mathrm{MJ} / \mathrm{kg}$

Rysunek 15. Wartość energetyczna wybranych materiałów, MJ/kg

Source: Grabowska et al. 2007.

Źródło: Grabowska i in. 2007.

\section{Conclusions}

Some of the numerous applications of raw materials derived from industrial hemp, presented in the article, have been known for centuries, and yet nowadays new directions of hemp application are soughtafter, studied and also implemented in practice, such as hemp-lime composites, used as a building material and bio-composites which are a substitute for commonly applied plastics, and pharmaceutical uses of hempseed oil. The positive environmental impact resulting from the cultivation of industrial

\section{Podsumowanie}

Niektóre z przedstawionych w artykule licznych zastosowań surowców pochodzących z upraw konopi włóknistych znane były od wieków, jednak obecnie poszukiwane i badane, ale również praktykowane są nowe kierunki zastosowań konopi jak np. kompozyty wapienno- konopne wykorzystywane jako materiał budowlany oraz bio- kompozyty będące substytutem masowo stosowanych tworzyw sztucznych, a także farmaceutyczne wykorzystanie oleju konopnego. Pozytywny wpływ środowiskowy wynikający z upraw 
hemp, such as a significant absorption of $\mathrm{CO}_{2}$, soil reclamation for the purposes of crop cultivation, the source of significant amounts of cellulose allowing us to spare forest resources, should be the main reason for the simplification of the procedures required to start its cultivation in many countries, including Poland, where we have bred hemp cultivars adapted to the local climate and soil conditions, guaranteeing a high yield. For farmers, it is often the acquisition and processing of the crop which pose greater problems than legal procedures associated with the cultivation. To increase the popularity of hemp cultivation in the countries where it is scarce, it is necessary to modernize the technical resources needed for harvesting crops and processing of hemp for various purposes. The return to large-scale cultivation of industrial hemp in Poland is an opportunity for the development of domestic agriculture and a chance to improve the economic situation of Polish farmers. A great demand for hemp crops, both domestically and in other European countries is noticeable. For this reason, Polish exports of raw hemp material (fibre, seed, shives) could positively affect the economic situation in Poland. konopi przemysłowych, taki jak np. znaczna absorpcja $\mathrm{CO}_{2}$, rekultywacja gleb na cele uprawne, źródło znacznych ilości celulozy, pozwalających poszanować zasoby leśne, powinien być głównym powodem dla uproszczenia procedury rozpoczęcia upraw $\mathrm{w}$ wielu krajach, w tym w Polsce gdzie wyhodowane zostały odmiany konopi włóknistych dostosowane do lokalnych warunków klimatyczno-glebowych, gwarantujące wysoki plon.Dla rolników nierzadko większym problemem niż same procedury prawne związane z uprawą jest pozyskanie oraz przetwórstwo plonów. Aby zwiększyć popularność upraw konopi w krajach, w których jest ona znikoma, niezbędne jest zmodernizowanie parku technologicznego związanego z zebraniem plonów oraz z przetwórstwem konopi na różne cele. Powrót do wielkoobszarowych upraw konopi przemysłowych w Polsce jest szansą dla rozwoju krajowego rolnictwa, szansą na poprawę sytuacji ekonomicznej polskich rolników. Obserwuje się duże zapotrzebowanie na plony,zarówno w kraju, jak i w innych państwach Europy. Dlatego też eksport polskich surowców konopnych (włókien, nasion, paździerzy) mógłby wpłynąć na poprawę sytuacji gospodarczej w Polsce.

\section{References/Literatura:}

1. Allin S. (2012), Building with Hemp. „Seed Press”, Ireland.

2. Barnat-Hunek D., Smarzewski P., Fic S. (2015), Mechanical and thermalproperties of hemp-limecomposites. CompositesTheory and Practice, 15, 1, s. 21-27.

3. Barnat-Hunek D., Smarzewski P., Brzyski P. (2016), Properties of hemp-flaxcomposites for use in the building industry. Journal of Natural Fibers (przyjęte do druku), http://dx.doi.org/10.1080/15440478.2016.1212764.

4. Barton J., Niemczyk A., Czaja K., Korach Ł., Sacher-Majewska B. (2014), Kompozyty, biokompozyty i nanokompozyty polimerowe. Otrzymywanie, skład, właściwości i kierunki zastosowań. Chemik, 68, 4, s. 280-287.

5. Bevan R., Woolley T. (2010), HempLime Construction: A Guide to Building with Hemp Lime Composites. BRE Press, Bracknell.

6. Bogacz E., Kicińska-Jakubowska A., Zimniewska M., Barbara Romanowska B. (2012), Charakterystyka włókien łykowych, Len i Konopie. Biuletyn Informacyjny Polskiej Izby Lnu i Konopi, 19, s. 37-44.

7. Campo M.C., Magalhães F.D., Mendes A. (2010), Carbon molecularsievemembranes from cellophanepaper. Journal of Membrane Science, vol. 350/1-2; s. 180-188.

8. Capelle A. (1996), Hemp: specialty crop for the paperindustry, W: Janick J, editor. Progress in newcrops, Arlington: ASHS Press; s. 384-388.

9. Demirbas A. (1997), Calculation of higher heating values of biomassfuels. Fuel, vol. 76; s. 431-434.

10. Dz.U. $2005 \mathrm{nr} 179$ poz. 1485: Ustawa z dnia 29 lipca 2005 r. o przeciwdziałaniu narkomanii.

11. Fic S., Brzyski P., Szewczak A., Jarosz-Hadam M. (2015), Wybrane właściwości lekkich kompozytów na bazie wypełniaczy celulozowych do zastosowania w budownictwie ekologicznym. Journal of Civil Engineering, Environment and Architecture, z. 62, $\mathrm{nr}$ 2, s. 61-70.

12. Garcia-Jaldon C., Dupeyre D., Vignon MR. (1998), Fibres from semi-retted hemp bundles by steam explosion treatment. Biomass and Bioenergy, vol. 14, s. 251-60.

13. Grabowska L., Kołodziej J., Burczyk H. (2007), Zastosowanie energetyczne konopi włóknistych. Problemy inżynierii rolniczej, 2, s. 19-26.

14. Gumuskaya E., Usta M., Balaban M. (2007), Carbohydratecomponents and crystallinestructure of organosolvhemp (Cannabissativa L.) bastfibers pulp. Bioresource Technology, vol. 98, s. 491-497.

15. Li S.Y., Stuart J.D., Li Y., Parnas R.S. (2010), The feasibility of convertingCannabissativa L. oilinto biodiesel. Bioresource Technology, vol 101/21, s. 8457-8460. doi:10.1016/j.biortech.2010.05.064

16. Linger P., Müssig J., Fischer H., Kobert J. (2003), Industrial hemp (Cannabiss ativa L.) growing on heavy metal contaminated soil: fibrequality and phytoremediation potential. Industrial Crops and Products, vol. 16; s. 33-42. doi:10.1016/S09266690(02)00005-5

17. Poisa L., Adamovics A. (2010), Hemp (Cannabissativa L.) as an environmentally friendly energy plant. Scientific Journal of Riga Technical University, vol 5, s. 80-85.

18. Rausch P. (1995), Verwendung von hanfsamenol in der kosmetik. In Bioresourcehemp. Nova-Institute, Cologne, Germany.

19. Rehman S.A., M., Rashid N., Saif A., Mahmood T., Han J.I. (2013), Potential of bioenergy production from industrial hemp (Cannabissativa): Pakistan erspective. Renewable and Sustainable Energy Reviews, Renewable and Sustainable Energy Reviews, vol. 18, s. 154-164. doi:10.1016/j.rser.2012.10.019

20. Sacilik K., Öztürk R., Keskin R. (2003), Some Physical Properties of Hemp Seed. Biosystems Engineering, Vol. 86/2, s. $191-198$. doi:10.1016/S1537-5110(03)00130-2 
21. Singh S., Deepak D., Aggarwal L., Gupta V.K. (2014), Tensile and FlexuralBehavior of HempFiberReinforcedVirgin-recycled HDPE Matrix Composites. Procedia Materials Science, vol. 6, s. 1696-1702.

22. Stanwix W., Sparrow A. (2014), The HempcreteBook - Designing and building with hemp-lime. Green Books, England.

\section{Websites/ Strony internetowe:}

23. www.bio-based.eu

24. www.iwnirz.pl

25. www.spliff.pl

26. www.steico.com 